\title{
Methodological Contribution to the Planning of Urban Passenger Transport in the Perspective of Environmental Sustainability
}

\author{
Shadia S. Assaf Bortolazzo*, Eugênio Cavallazzi, Amir Mattar Valente \\ Department of Civil Engineering (CTC - ECV), Postgraduate Program in Transport Engineering and Territorial Management (PPGTG), \\ Federal University of Santa Catarina (UFSC), Brazil
}

Copyright $\mathrm{C} 2018$ by authors, all rights reserved. Authors agree that this article remains permanently open access under the terms of the Creative Commons Attribution License 4.0 International License

\begin{abstract}
This study aims to present the results of a systematic literature research developed to identify methodologies, models and scientific planning methods, and valuation of environmental costs in transport, which should serve as theoretical and technical basis for the development of a specific methodological contribution, for sustainable planning, reduction of energy consumption, low pollutant emissions, the urban environment of cities, and for the transport of people. The research carefully selected articles that have demonstrated the potential application of the concepts of sustainable logistics, green logistics and low-carbon logistics in public transport of people. In the second stage, applications directed to transport planning and valuation of environmental costs in transport were identified in these articles, such as pollutant emissions and energy consumption to standardize the concepts, understand them and use them to build a model. It was possible to identify 20 different methods with common objectives of transport sustainability and to build a methodological proposal of sustainable urban transport planning (MPTS-URB), whose contribution is a joint approach of sustainability, economic study, demand and transportation capacity factors, in which all work in harmony. Following this research, it is intended to apply the methodology built - MPTS-URB in the sample environment and to analyze its results.
\end{abstract}

Keywords Planning Methods, Urban Transport, Sustainable Planning, Sustainable Logistics, Environmental Valuation

\section{Introduction}

Transportation is essential to modern life. It is what makes most social and economic activities possible
(D'AGOSTO, 2015). The transport sector is the basis for the stability of any economy in the current global market (Valente et al., 2012). The indispensability of transportation puts their study - modes, technologies, travel time, demand, and logistical capacity - in constant evidence in the urban transportation planning, to improve the social, economic and environmental conditions of urban mobility. Because of its importance in the structuring and processing of natural and social landscapes, and as one of the largest consumers of non-renewable resources, transportation is a key part in the sustainable development equation (Vasconcellos, 2011).

Since it was identified as a global priority by the United Nations in the early 1980s, sustainable development was defined as meeting the needs of the present without compromising the ability of future generations to meet their own needs (WCED, 1987 apud SEABRA, 2013). It is consensual; however, that sustainable planning consists of the reconciliation of three dimensions: social, economic and environmental, in which each dimension involves a complex system of differentiated and sometimes conflicting objectives and interests. However, the design of any sustainability model should reflect the balance between these dimensions, thus adapted to the standard definition, sustainability in transportation is to meet current and future accessibility and mobility needs, with positive impacts in the environmental, economic and social (SEABRA, 2013). Thus, environmentally sensitive, the urban sustainable mobility requires modification of the conventional urban transportation planning scheme, transferring them to a sustainable model with less negative impacts on the environment (ERICSS ON et al., 2006).

In logistics area, methods of transportation planning aiming more efficient use of energy and lower emissions of pollutants are advancing as current research objectives in transport and applications as: green logistics (LIN et al, 2014), low - carbon logistics (Yang et al, 2013) and 
sustainable logistics (Ciliberti et al., 2007). In the context of cities, the traditional approach of transportation planning, freight and passengers, given more emphasis to economic and financial aspects (MCKINNON, 2010). However, it has undergone adjustments since the last decade, to also achieve the social and environmental aspects of sustainable urban mobility, such as a growing awareness of society on the need to promote better management of freight transport activities as well as daily displacement distances of the people (Lin et al., 2014).

This article, following this introduction, presents the results of a literature review, Chapter 2, built from a systematic methodology revision (TRANFIELD, DENYER and SMART, 2003) that were carefully selected, studies demonstrating potential application of concepts of sustainable logistics, green and low - carbon consumption in transportation planning of the cities, as well, as methods of environmental valuation and performance improvement in transport from the perspective of sustainability. This review formed the conceptual framework for the construction of an own methodology that aims at sustainable management of urban passenger transport, being called Sustainable Urban Transport Planning Method (MPTS-URB), presented in Chapter 3. Chapter 4 presents the final recommendations and motivation for future work.

\section{Literature Review}

\subsection{Logistics, Mobility and Sustainability in the Urban Context}

The practice of logistics in an approach that considers social and environmental aspects seems to be associated with low - carbon logistics concepts, green logistics and sustainable logistics which relate, because while employing different terms, they intende to achieve common goals (Xuezhong et al. , 2011).The low carbon logistics can be considered in a less comprehensive scope, since it is concentrated solely on reducing emissions of $\mathrm{CO}_{2}$ and thus, in the transport scope, it is more recurrent in research that deals with alternatives to replace fossil fuels and non-motorized transport practices (Rodrigues et al, 2010;. Yang et al, 2013.). The green logistics aims to coordinate the activities of transport - freight, services, people - so that the needs are met at a lower cost to the environment (QUIUMENTO, 2011).It is a management practice that promotes the adoption of measures aimed at reducing environmental impacts (LAI et al., 2012), among which we can mention, in addition to $\mathrm{CO}_{2}$ reduction, waste reduction, climate changes, excessive and unplanned use of natural resources, environmental accidents, noise and soil degradation (Sarkis et al., 2004; Sarkis and LAI, 2008).

In a greater perspective, sustainable logistics implies reconciling environmental, economic and social aspects in human activities (Brundtland Commission, 1987). The social aspects should emphasize a comprehensive proposal that promotes changes in the institutional framework, as well as political and economic choices (Ciliberti et al., 2007, Sarkis et al, 2011; Tseng et al, 2013.). Thus, it is understood the application of sustainable logistics, linked to sustainable planning in cities, with better use of natural resources and alternative mobility for society in general and impacting quality of life. Logistics, mobility and sustainability in the urban environment are the condition of people moving in the city in an equitable and environmentally efficient way. They are directly related to transportation planning and fair accessibility of the city, either by motorized or non-motorized means of transportation.

\subsection{Environmental Valuation Methods}

According to Pearce (1993), each environmental rating method has its own limitations in capturing different types of environmental feature values, there is no way to verify the efficiency relative to one another, even because there is no way to pinpoint the actual value of an environmental resource. For the author, the objective evaluation of the efficiency of the method for the specific case and the information available to the intended study must be considered. Rosemary and Maia (2011) classify the methods of environmental valuation in direct and indirect: the first attempts to capture the preferences of people using "hypothetical markets" as references, while the latter seeks to obtain the "resource value" through a production function. Indirect methods relate the impact of environmental changes to products with market prices. Romero and Maia (2011) present a summary of the main direct and indirect methods, hitherto mostly found in bibliographies, and their respective sub-groups (Figure 1).

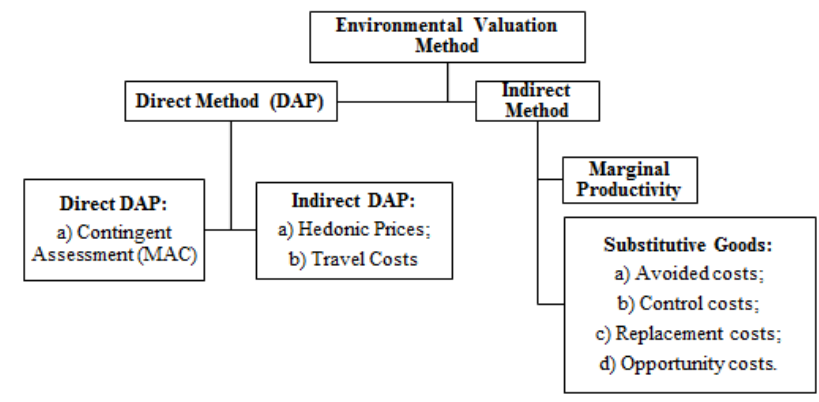

Figure 1. Methods of environmental valuation. Adapted from Romeiro and Maia (2011).

The indirect method Avoided Cost estimates the value of an environmental resource through spending on preventive activities (LANDMANN et al., 2007). In this sense, Leal Jr. and D'Agosto (2012) consider that the larger the stock of natural capital, the higher the country's ability to generate income in the future. In other words, the choice of this consumption represents how much the society is giving up its natural assets to invest in sustainable solutions, thought 
in long term.

Under the focus of transport, indirect methods such as Control Costs, or direct methods like the MAC, can help in planning sustainable distribution networks logistics and green logistics (Sarkis et al., 2011). A methodology based on pollution Control Costs come closer to the method of Avoided Costs, which seeks to estimate the expenses generated to offset the damage caused by pollution, considering the quality of the analyzed environmental resource (LANDMANN et al., 2007).This method, from the standpoint of transportation planning, can be seen with optimism, because it relates directly to the reduction of $\mathrm{CO}_{2}$ emissions, as they can predict lower costs of avoiding pollution, than to the restoring the destroyed environment, or even the loss of production arising from the environmental impact.

The Indirect Method of Contingent Valuation (MAC) makes use of statistics public consultations, such as interviews, to directly capture the individual values of use and non-use, assigned to a natural resource (Silveira et al., 2013).The questioning may be voluntary like the willingness to pay (WTP), or induced like multiple choice quizzes (DA COSTA et al., 2015).It is required, however, special care in planning and execution of research so that it does not direct the results and compromise the analysis of the estimates (PALMER, MAIA, 2011).However, it is recommended to have caution in the use of environmental valuation methods, and the combined use of other non monetary criteria of environmental impact assessment, as Templates Decision Support, or Multi-criteria (MCDA Multiple Criteria Decision Aid), especially when the impact or environmental resource can become irreversible (Pearce, 1993; Andrade and Romeiro, 2011; Ribeiro, 2015; Leal Jr. and D'Agosto, 2012).

MCDA methodologies seek to build an understanding of what is intended by the main players (stakeholders), so that they can identify, organize, measure and integrate the aspects they perceived as important in the context of the problem, and see the consequences of the alternatives of what was chosen as important (Ensslin; Montibeller; NORONHA, 2001).To Zamcopé et al., (2010) the MCDA methodology will only be appropriate to the specific context in which it was developed, because it allows the customization of the decision variables used in building the model.

Landmann et al (2007) have listed some methods that were used for evaluation of air pollutants emitted by the transportation sector. The author made an assessment of the advantages and disadvantages of each, which is presented in Table 1.

As for the emissions of anthropogenic gases by the transport sector, research involving changes in the composition of fuels, such as adding alcohol to gasoline and biofuel study also influenced the reduction of emissions, opening a new front to the development of methodologies for reducing emissions of vehicle pollutants. Even so, for Landmann et al. (2007), there is no clearly defined or widely accepted methodology to value or reduce costs and impacts of air pollution. The methods available in the literature are quite complex and involve many uncertainties (ORTIZ et al., 2011). They imply a hard interdisciplinary work using concepts and professionals from various sectors of knowledge, time and resources (LEAL JR, D'AUGUST, 2012). Studies of this size are made almost exclusively in developed countries. In Brazil and other countries in cultural and economic rise, the adaptation of methodologies, indices and results of the first world countries is common (LANDMANN et al., 2007).Officially in Brazil, public managers in the environmental area (Ministry of the Environment - MMA), transport (National Public Transport Agency - ANTP), and energy (Ministry of Mines and Energy - MME) have adopted as a methodology for the valuation of pollution costs, the so-called ASIF Methodology, English Activity, Structure, Intensify and Fuel.

Table 1. Methods of estimation of environmental costs in transport projects: assessment of the advantages and disadvantages by the sight of Landmann et al. (2007). Adapted by the author from Landmann et al (2007)

\begin{tabular}{|c|c|c|}
\hline Method & Advantages & Disadvantages \\
\hline $\begin{array}{l}\text { Cost of Damage to Health and } \\
\text { Human Capital }\end{array}$ & $\begin{array}{l}\text { Established and internationally accepted; } \\
\text { Often cited in bibliographies. }\end{array}$ & $\begin{array}{l}\text { Complex (high consumption of time and resources); } \\
\text { Poor accuracy of the results; } \\
\text { Difficult data collection in developing countries; } \\
\text { You cannot internalize all indirect damages. }\end{array}$ \\
\hline DAP (Willingness to Pay) & Considers the individual's point of view; & $\begin{array}{l}\text { Ethical problems of social values (differences between classes); } \\
\text { Difficulty of the ordinary individual to assess risks. }\end{array}$ \\
\hline Hedonic Prices & $\begin{array}{l}\text { Does not value the human life; } \\
\text { Often cited in bibliographies; } \\
\text { There is no consolidated methodology } \\
\text { application flexibility) }\end{array}$ & $\begin{array}{l}\text { Believes that the real estate market is always sensitive to variation } \\
\text { of air pollution; } \\
\text { High correlation between air pollution and other impacts of heavy } \\
\text { traffic on the value of real estate; } \\
\text { Difficulty in obtaining prices in the real estate market; }\end{array}$ \\
\hline Cost Per Capita & Avoids direct valuation of human life. & $\begin{array}{l}\text { It covers only material losses; } \\
\text { Very simple method. }\end{array}$ \\
\hline Control Costs & $\begin{array}{l}\text { Ease of obtaining data; } \\
\text { It requires few resources; } \\
\text { It uses familiar variables to transport } \\
\text { technicians. }\end{array}$ & $\begin{array}{l}\text { May face resistance concerning the change of approach; } \\
\text { Needs to gain maturity using it in various projects and comparing } \\
\text { it with other methods. }\end{array}$ \\
\hline
\end{tabular}


The ASIF methodology was introduced by the Intergovernmental Panel on Climate Change (IPCC Intergovernmental Panel on Climate Change) in its first report in 1991, and that includes four lines of action to reduce fossil energy consumption in transport and therefore reduce $\mathrm{CO}_{2}$ emissions and local pollutants, they are: (a - activity) reduced activity intensity ( $\mathrm{S}$ - structure) infrastructure offering, (I - intensity) decreased energy intensity and (F-fuel) choice of low-carbon energy sources (WMO / UNEP, 1990).This methodology has been used worldwide for the development of emissions inventories and power consumption, as it enables $\mathrm{CO}_{2}$ emissions to energy, making it possible to monetise emissions.

By addressing energy costs, prospects and availability of this feature to a horizon of 30,50 or 100 years in the transportation industry, it makes us think mainly in Brazil, about sources of oil, natural gas, and also biofuels ( ethanol and biofuels), which can be considered a complex issue, both for the technical aspects involved, as political, economic and tributary specificities (MARTINS, 2010).Thus, it is pertinent to ask: how much it will cost and how available will these energy sources be in the future? The valuation methodologies of energy cost may include stages of the energy life cycle, or full (IAEA, 2006). As the transportation of final energy consumption service, the cost of it is indirectly linked to the steps leading up to the consumer (ZHANG; Baranzini, 2004). As an example, there is the final value of passenger fare, the cost of freight, among others.

Energy efficiency measures will meet the objectives of the methodologies and policies in the medium and long term, favorable to the conscious use of natural resources. According to the World Bank (2006) there are several potentials, such as: (a) the cost of the economy is smaller than the power generation, in which saving finite resources increases the security of supply, (b) increased productivity generates micro and macroeconomic gains as well as competitiveness, (c) the reduction of environmental impacts, in particular greenhouse gases. However, this aspect is not unanimous, since for some sectors the energy is an agent of development, production and profits (Guimarães et al., 2014).

Regarding the institutional measures of energy efficiency, specifically for the transport sector, national plans and policies have been developed in Brazil, bearing in mind short, medium and long-term actions (10, 30 and 50) (EPE; MME, 2014) as shown in Table 2.

The Academy has also developed methodologies for energy valuation with goals to improve energy efficiency, $\mathrm{CO}_{2}$ reductions and the total energy consumption in the transport area. The Inventory Lifecycle Procedure (ICV) proposed by (D'AUGUST; OLIVEIRA, ASSUMPÇÃO, 2014) examined the results of six different energy alternatives for urban transport by bus in the city of Rio de Janeiro, for total energy consumption, renewable energy and net $\mathrm{CO}_{2}$ emissions.

Guimarães et al., (2014) analyzed the evolution of energy efficiency in passenger and freight transportation sector in Brazil, using descriptive statistical techniques applied in a series of historical data and inventories, obtaining an energy consumption curve in this sector, in different modes (air, road, rail and waterway) between the years 1970 and 2010. Other authors highlight the potential of modal freight transfer as a measure of energy use reduction (Uherek et al, 2010; LEAL JR, D'AUGUST, 2012; STEENHOF, WOUDSMA; SPARLING，2006; STANLEY; Hensher; LOADER 2011).

For Liimatainen and Pöllänen (2010), the inter-modality is an option that, in addition to promoting the improvement in energy efficiency in transport, contributes to balancing the transmission matrix. Vyas et al., (2013) consider that multi-modal transport alternatives can provide sustainable results regarding energy and $\mathrm{CO}_{2}$ emissions, provided it is operationally well managed.

Table 2. Policy and Institutional Energy Efficiency Measures in Transport in Brazil. Adapted by EPE author; MME (2014)

\begin{tabular}{|l|l|}
\hline \multicolumn{1}{|c|}{ Policies and Measures } & \multicolumn{1}{c|}{ Description / Engine Purpose / Goals } \\
\hline $\begin{array}{l}\text { Air Pollution Control } \\
\text { Program by Motor Vehicles } \\
\text { (PROCONVE). }\end{array}$ & $\begin{array}{l}\text { Reduce and control air pollution from mobile sources (motor vehicles), setting time limits, emission ceilings and } \\
\text { establishing technical requirements for motor vehicles, domestic and imported. }\end{array}$ \\
\hline $\begin{array}{l}\text { Labeling of light vehicles } \\
\text { (PBE). }\end{array}$ & The label aims to inform consumers the energy efficiency level of the product purchased. \\
\hline $\begin{array}{l}\text { PNLT - National Plan of } \\
\text { Logistics and Transport. }\end{array}$ & $\begin{array}{l}\text { The plan aims to rescue the plan and considers logistics aspects, costs involved in the whole transport chain, } \\
\text { starting from the origins to the destinations, sustainability and the environment, reduce regional inequalities, } \\
\text { inducing sustainable development and proper use of railway modalities and waterways in freight transportation. } \\
\text { The plan's goal is that in 2031 the transport matrix reaches the following distribution: road 38\%, rail } 43 \%, \\
\text { waterway 6\%, pipeline 4\% and cabotage 9\%. }\end{array}$ \\
\hline Innovate Auto. & $\begin{array}{l}\text { Avoided reductions of 42 million CO2eq, reduction of "flex" vehicles' IPI tax and gasoline up to } 1,000 \mathrm{cc} \text {. The } \\
\text { measure aims to encourage the production and consumption of vehicles that consume less fuel. More } \\
\text { competitiveness, technology and safety for the cars produced and sold in Brazil. The target goal is } 17.26 \mathrm{~km} / 1 \text { (gas) } \\
\text { and } 11.96 \mathrm{~km} / 1 \text { (ethanol). Today, the national average consumption is 14 km /1 (gasoline) and 9.71 km /1 } \\
\text { (ethanol). }\end{array}$ \\
\hline $\begin{array}{l}\text { PNMU - National Policy on } \\
\text { Urban Mobility. }\end{array}$ & $\begin{array}{l}\text { It aims to integrate the different modes of transport and to improve the accessibility and mobility of people and } \\
\text { freight in the city's territory }\end{array}$ \\
\hline
\end{tabular}




\subsection{Performance Improvement Methods in Transport in the Perspective of Sustainability}

The development of tools that provide a choice of different transport modes is crucial to form the organization strategy, public or private, of a country or city, and the assessment of their socio-economic and environmental performance used for that purpose (Novaes, 2004). Under the sustainable point of view, such a strategy has been studied through transport optimization methods, which, among the objectives is to minimize any environmental property such as energy (Ferreira, RS and Neto, JCL, 2015; Vyas et al. , 2013 Erdogan and Miller-Hooks, 2012; D'Agosto; Oliveira, Assumption, 2014), $\mathrm{CO}_{2}$ emissions and less fuel consumption (Scott et al, 2010;. Palmer, A., 2008; Ericson et al., 2006), issue of greenhouse gases (Ferreira, BV and Rosa, RA, 2015; Bektas and Laporte, 2011; Palmer, A., 2008; . Van Woensel et al, 2001; Kyrb et al, 2000). biofuels (Leal Jr. and D'Agosto, 2012; D'Agosto and Ribeiro, 2004; D'Agosto; Oliveira, Assumption, 2014), among others.

Eco-efficiency in transportation can be understood as optimizing some environmental property, such as the consumption of fuels or emission of pollutants, while maintaining the operation of this service. It is being studied by Silva (2004), D'Agosto and Ribeiro (2004), Salgado (2007), Cheon et al. (2009), Leal Jr. and D'Agosto (2012) in order to demonstrate that it is possible to reconcile environmental issues with those of operation and transportation costs. De Oliveira and D'Agosto (2014) are developing an Index Logistics Sustainability (ILS) verification procedure, which aims to support companies in possible decision making in relation to the sustainability of their supply chain. Such research to improve and assess the eco-efficient performance in transportation come to add to the traditional transportation logistics - cost optimization, best route, shorter time, among others - environmental indicators, such as the balanced use of energy resources and materials, reduction of anthropogenic gases and conservation of natural resources.

Table 3 below shows the compiled results of the systematic literature review developed in this article, which focuses on the relationship of the terms sustainable logistics, green logistics, low-carbon logistics, valuation of environmental costs and energy efficiency with the sustainable planning of transport. 
Methodological Contribution to the Planning of Urban Passenger Transport

in the Perspective of Environmental Sustainability

Table 3. List of works resulting from the systematic literature review in which improvement methodologies have been identified in transport with a focus on sustainability. Source: Prepared by the author.

\begin{tabular}{|c|c|c|c|c|c|c|}
\hline Methodology & Sector & Objective of the method & Concepts covered & $\begin{array}{c}\text { Criteria used in the } \\
\text { methodology }\end{array}$ & Author(s) Year & $\begin{array}{c}\text { Country of } \\
\text { origin }\end{array}$ \\
\hline $\begin{array}{l}\text { Total Cost of Vehicular } \\
\text { Emission (CEV) }\end{array}$ & $\begin{array}{l}\text { Urban transport } \\
\text { network. }\end{array}$ & $\begin{array}{l}\text { Monetary valuation of air pollution to be used } \\
\text { in feasibility analysis of transport projects. }\end{array}$ & $\begin{array}{l}\text { Valuation of environmental } \\
\text { costs; transportation } \\
\text { planning. }\end{array}$ & $\begin{array}{l}\text { Suppliers' data (cost of } \\
\text { equipment of emission control - } \\
\text { catalysts). }\end{array}$ & Landmann et al (2007) & Brazil \\
\hline $\begin{array}{c}\text { Method of modal choice } \\
\text { (MEM) }\end{array}$ & Freight transport. & $\begin{array}{l}\text { Improve economic and environmental } \\
\text { performance of road transport through } \\
\text { eco-efficiency actions. }\end{array}$ & $\begin{array}{l}\text { Biofuels; Transportation } \\
\text { Planning; }\end{array}$ & $\begin{array}{c}\text { Creation of hypotheses using } \\
\text { modal alternatives; } \\
\text { Multi-criteria analysis. }\end{array}$ & $\begin{array}{l}\text { Leal Jr. and D'Agosto } \\
\qquad(2012)\end{array}$ & Brazil \\
\hline $\begin{array}{l}\text { Investment analysis } \\
\text { (cost-benefit applied to } \\
\text { transport) }\end{array}$ & $\begin{array}{l}\text { Urban passenger } \\
\text { transport. }\end{array}$ & $\begin{array}{l}\text { Identify fuel options and propulsion } \\
\text { technologies applicable to public transport by } \\
\text { bus displaying the emission reduction potential } \\
\text { of } \mathrm{CO}_{2} \text { in the short-term. }\end{array}$ & $\begin{array}{c}\text { Sustainable transport, } \\
\text { Valuation of environmental } \\
\text { costs of low-carbon policy, } \\
\text { Biofuels. }\end{array}$ & $\begin{array}{c}\text { Comparative analysis of } \\
\text { operating costs, investment } \\
\text { costs (biofuels and technology) } \\
\text { and environmental benefits of } \\
\mathrm{CO}_{2} \text { reduction and energy } \\
\text { efficiency. }\end{array}$ & $\begin{array}{l}\text { D'Agosto, Ribeiro and } \\
\text { Souza (2013) }\end{array}$ & Brazil \\
\hline $\begin{array}{l}\text { External costs of transport } \\
\text { paid by the society }\end{array}$ & $\begin{array}{c}\text { Urban } \\
\text { transportation. }\end{array}$ & Calculation of external costs. & $\begin{array}{l}\text { Valuation of environmental } \\
\text { costs; }\end{array}$ & $\begin{array}{l}\text { Inventories (circulating fleet, } \\
\text { new vehicles, vehicle } \\
\text { emissions) }\end{array}$ & $\begin{array}{c}\text { Prado and Gonçalves } \\
\text { (2013) }\end{array}$ & Brazil \\
\hline $\begin{array}{c}\text { Green - Vehicle Routing } \\
\text { Problem } \\
\text { (G-VRP); Pollution } \\
\text { Routing Problem (PRP); } \\
\text { Time dependent Vehicle } \\
\text { Routing Problem } \\
\text { (TDVRP) }\end{array}$ & $\begin{array}{l}\text { Urban road } \\
\text { transport of } \\
\text { freight, supply } \\
\text { chain }\end{array}$ & $\begin{array}{l}\text { Calculation of emissions; Reduction of } \\
\text { emissions of greenhouse gases; Fuel } \\
\text { Reduction; Energy efficiency; Optimization. }\end{array}$ & $\begin{array}{l}\text { Green logistics; } \\
\text { Low Carbon Logistics; } \\
\text { Sustainable logistics. } \\
\text { Sustainable transport; } \\
\text { Transportation Planning. }\end{array}$ & $\begin{array}{l}\text { Routing problem in transport } \\
\text { under the sustainable approach. } \\
\text { Problem with queues; }\end{array}$ & $\begin{array}{l}\text { Sarkis et al (2004); Ericson } \\
\text { et al (2006); } \\
\text { Bektas and Laporte (2011); } \\
\text { Ribeiro and Laporte } \\
\text { (2012); Erdogan and } \\
\text { Miller-Hooks (2012); } \\
\text { Ferreira and Rosa (2015). }\end{array}$ & $\begin{array}{c}\text { USA; } \\
\text { Sweden; } \\
\text { UK and Canada; } \\
\text { Brazil } \\
\text { United Kingdom } \\
\text { USA; } \\
\text { Brazil } \\
\end{array}$ \\
\hline Willingness to pay (DAP) & $\begin{array}{l}\text { Transport; Public } \\
\text { health }\end{array}$ & $\begin{array}{l}\text { Relate the costs of health and air pollution by } \\
\text { carrier in the city of São Paulo and the } \\
\text { metropolitan area. Implement actions of } \\
\text { pollution reduction. }\end{array}$ & $\begin{array}{l}\text { Valuation of environmental } \\
\text { costs; }\end{array}$ & $\begin{array}{l}\text { Interviews; Inventories (air } \\
\text { pollutants). }\end{array}$ & Ortiz et al (2011) & Brazil \\
\hline Comparative analysis & $\begin{array}{l}\text { Road transport of } \\
\text { freight. }\end{array}$ & $\begin{array}{l}\text { Review and compare the results of six models } \\
\text { used in practice to reduce fuel consumption } \\
\text { and emissions of greenhouse gases; }\end{array}$ & $\begin{array}{l}\text { Energy efficiency; Green } \\
\text { logistics; Transportation } \\
\text { planning; Scripting. }\end{array}$ & $\begin{array}{l}\text { Simulation; Numerical } \\
\text { comparison of field results in } 4 \\
\text { different scenarios: load } \\
\text { variation, speed, route (slope) } \\
\text { and acceleration. }\end{array}$ & $\begin{array}{l}\text { Demir; Bektas; Laporte } \\
\text { (2011) }\end{array}$ & $\begin{array}{l}\text { United } \\
\text { Kingdom; } \\
\text { Canada }\end{array}$ \\
\hline Inventory Lifecycle (ICV) & $\begin{array}{l}\text { Urban public } \\
\text { passenger } \\
\text { transport. }\end{array}$ & $\begin{array}{l}\text { Analyze the results obtained from the use of } \\
\text { six different fuels (alternative energy) in urban } \\
\text { public transport in the city of Rio de Janeiro, } \\
\text { considering the total energy consumption, } \\
\text { renewable energy and net } \mathrm{CO}_{2} \text { emissions. }\end{array}$ & $\begin{array}{l}\text { Sustainable transport; } \\
\text { Biofuels; Alternative energy } \\
\text { sources; Energy Efficiency. }\end{array}$ & $\begin{array}{l}\text { Lifecycle Analysis (ACV); } \\
\text { Lifecycle Inventory (ICV). }\end{array}$ & $\begin{array}{l}\text { D'Agosto, Oliveira and } \\
\text { Assumption (2014). }\end{array}$ & Brazil \\
\hline $\begin{array}{l}\text { Conceptual analysis: } \\
\text { scenarios } \\
\text { (20 and } 50 \text { years old). }\end{array}$ & $\begin{array}{l}\text { Urban passenger } \\
\text { transport. }\end{array}$ & $\begin{array}{l}\text { Check the reduction of } \mathrm{CO}_{2} \text { emissions from } \\
\text { five actions: reducing the distance traveled by } \\
\text { cars, increased non - motorized shared } \\
\text { transport, increased vehicle occupancy rates, } \\
\text { reducing the use of fuel, increased vehicle } \\
\text { efficiency. }\end{array}$ & $\begin{array}{l}\text { Sustainable Transportation, } \\
\text { Energy Efficiency, } \\
\text { Transport Planning. } \\
\text { Urban planning. }\end{array}$ & $\begin{array}{l}\text { Statistical data projections of } \\
\mathrm{CO}_{2} \text { emissions in urban } \\
\text { transport; Emission inventories. }\end{array}$ & $\begin{array}{l}\text { Stanley, Hensher and } \\
\text { Loader (2011); }\end{array}$ & Australia \\
\hline
\end{tabular}




\begin{tabular}{|c|c|c|c|c|c|c|}
\hline Methodology & Sector & Objective of the method & Concepts covered & $\begin{array}{l}\text { Criteria used in the } \\
\text { methodology }\end{array}$ & Author(s) Year & $\begin{array}{c}\text { Country of } \\
\text { origin }\end{array}$ \\
\hline Modal transfer & Freight transport & $\begin{array}{l}\text { Demonstrate that the modal shift between road } \\
\text { and rail in cross-border trade is essential to } \\
\text { reducing energy consumption and emissions of } \\
\text { greenhouse gases. }\end{array}$ & $\begin{array}{l}\text { Sustainable transport; } \\
\text { Modal shift; Valuation of } \\
\text { energy costs; } \\
\text { Energy efficiency. }\end{array}$ & $\begin{array}{l}\text { Application of decomposition } \\
\text { techniques and exploitation of } \\
\text { scenarios; } \\
\text { Increased rates policy (fuel and } \\
\text { freight); }\end{array}$ & $\begin{array}{l}\text { Steenhof, Woudsma and } \\
\text { Sparling (2006) }\end{array}$ & Canada \\
\hline $\begin{array}{c}\text { Eco-efficiency } \\
\text { Management Program } \\
\text { (EEMP) }\end{array}$ & $\begin{array}{l}\text { Road transport } \\
\text { freight. }\end{array}$ & $\begin{array}{l}\text { Propose a road fleet operation management } \\
\text { program based on the minimization of fuel } \\
\text { consumption and valuation of environmental } \\
\text { and economic costs. Identify eco-efficiency } \\
\text { indicators of the fleet. }\end{array}$ & $\begin{array}{l}\text { Eco-efficiency, Transport } \\
\text { management; Sustainable } \\
\text { transport; Energy Efficiency; } \\
\text { Atmospheric pollution. }\end{array}$ & $\begin{array}{l}\text { Case study applied in inland } \\
\text { logistics fleet operation in } \\
\text { support of Infraero's aircraft } \\
\text { (airport of Rio de Janeiro). }\end{array}$ & $\begin{array}{l}\text { D'Agosto and Ribeiro } \\
\text { (2004). }\end{array}$ & Brazil \\
\hline $\begin{array}{l}\text { Computational model of } \\
\text { data envelopment analysis } \\
\text { (Data Envelopment } \\
\text { Analysis - DEA) Online }\end{array}$ & Shipping freight. & $\begin{array}{l}\text { Present an alternative to increase the energy } \\
\text { efficiency of vessels. }\end{array}$ & $\begin{array}{c}\text { Energy efficiency; } \\
\text { Sustainable transport; } \\
\text { Valuation of energy costs; }\end{array}$ & $\begin{array}{l}\text { Operational research through a } \\
\text { data envelopment analysis } \\
\text { model (comparatively } \\
\text { analyzing vessels as the energy } \\
\text { performance in real time). } \\
\end{array}$ & $\begin{array}{l}\text { Ferreira, R.S and Neto, } \\
\text { JCL (2015). }\end{array}$ & Brazil \\
\hline $\begin{array}{l}\text { Sustainable Urban } \\
\text { Mobility Index (IMUS). }\end{array}$ & $\begin{array}{l}\text { Urban passenger } \\
\text { transport; Urban } \\
\text { mobility. }\end{array}$ & $\begin{array}{l}\text { Identify challenges and prospects for } \\
\text { evaluation and improvement of sustainable } \\
\text { urban mobility; Test by applying the Mobility } \\
\text { Index Sustainable Urban (IMUS). }\end{array}$ & $\begin{array}{l}\text { Sustainable Transportation; } \\
\text { Indicators of sustainable } \\
\text { mobility; }\end{array}$ & $\begin{array}{l}\text { Comparison of results; } \\
\text { Sustainable Urban Mobility } \\
\text { Index (IMUS). }\end{array}$ & $\begin{array}{l}\text { Oliveira, GM; Rodrigues } \\
\text { da Silva, AN (2015) }\end{array}$ & Brazil \\
\hline $\begin{array}{l}\text { A methodology for } \\
\text { calculating } \mathrm{CO}_{2} \\
\text { emissions from transport } \\
\text { and an } \\
\text { evaluation of the impact of } \\
\text { European Union emission } \\
\text { regulations. }\end{array}$ & $\begin{array}{l}\text { Freight transport; } \\
\text { Supply chain. }\end{array}$ & $\begin{array}{l}\text { It is part of the CRSC (Carbon Regulated } \\
\text { Supply Chains) Project. It is studying the } \\
\text { development of a methodology for calculating } \\
\text { carbon dioxide emissions from transportation, } \\
\text { and a calculation tool to apply this } \\
\text { methodology. }\end{array}$ & $\begin{array}{l}\text { Environmental assessment } \\
\text { of } \mathrm{CO} 2 \text { emissions in } \\
\text { transport; } \\
\mathrm{CO} 2 \text { reduction } \\
\text { in transportation of supplies. }\end{array}$ & $\begin{array}{l}\text { Methods of quantifying } \\
\text { emissions in transport. } \\
\text { Literature review. } \\
\text { Comparative; } \\
\text { Payload increase; } \\
\text { Modal choice. }\end{array}$ & Roel te Loo (2011) & Netherlands \\
\hline
\end{tabular}




\section{Planning Method of Sustainable Passenger Urban Transport (MPTS-URB)}

This chapter presents the MPTS-URB developed method, which aims to collaborate with the planning of urban transport in cities, to join in the demand forecasting issues, capacity, network distribution and modes of transport, environmental energy use and pollutant emissions $\left(\mathrm{CO}_{2}\right)$, introducing a quantitative analysis of these factors, as relevant to environmental sustainability in the planning process. For this, the concepts based on literature review of this research were used as the method of Avoided Costs, the ASIF Methodology and MCDA, as well as new concepts, based from the knowledge acquired, such as the Cost of Green Logistics (CLV).

The CLV is here understood as the sum of the energy costs (fuel) and $\mathrm{CO}_{2}$ emissions of the fleet (considering all the sample forms of transport - transport network), motorized and non - motorized, and will result from the MPTS- URB. The method meets the choice and distribution of network modes, fleet characteristics (efficiency, fuel technology), distances (network design), demand study (planning and land use) and vehicle capacity. It was developed in four phases as follows: (1) diagnosis, (2) Economic Study (3) Sustainable Planning and (4) Critical Analysis.

Phase 1 aims to diagnose the actual situation of the sample (transport network) and has thus the emission inventories, energy use and modal distribution, using the ASIF methodology (IPCC, 2006). Phase 2 seeks to bring to the analysis environment and network planning, other actors in the management environment, such as financing, fundraising and investment, bearing in mind that, as important as the strategic planning of urban mobility, is the economic viability and optimization of resources. It is intended to associate the Method of Avoided Costs with this phase. Phase 3 is the phase where the scenarios of the transmission network will be planned with a view to environmental sustainability (service demand with less $\mathrm{CO} 2$ emissions and lower energy consumption), with the premise to improve outcomes diagnosed in Phase 1, knowing the forecast of Phase 2 investments. This phase will use the Multi-criteria Methodology (MCDA), for including the involvement of key private players to the sample planning process (transport network) in the decision making. Phase 4 is the calculation of CLV for the scenarios planned in the previous phase, and the critical analysis of these. The CLV is shown in equation [1], which considers the sum of the energy consumption costs $(\mathrm{E})$ and $\mathrm{CO}_{2}$ emission costs $(\mathrm{P})$ for the five modes $(\mathrm{m})$ considered in the method as shown in Phase 1 of Figure 2.

$$
C L V=\sum_{m=1}^{n}\left(E_{m} \times e\right)+\left(P_{m} \times p\right)
$$

Here:

$\mathrm{CLV}=$ green logistics costs;

$\mathrm{m}=$ the transport network mode or scenario ranging from $\mathrm{m}=1$ to $\mathrm{m}=\mathrm{n}$;

$\mathrm{E}=$ energy consumed by transport mode $\mathrm{m}(\mathrm{m}=1.2 \ldots .$, n);

$\mathrm{P}=$ carbon dioxide emissions $\left(\mathrm{CO}_{2}\right.$ by mode of transport $\mathrm{m}(\mathrm{m}=1.2 \ldots ., \mathrm{n})$;

$\mathrm{e}=$ power conversion constant ( $\mathrm{kep} /$ pass. $\mathrm{km})$ currency value $(\mathrm{R} \$)$;

$\mathrm{p}=$ pollutant conversion constant $\left(\mathrm{g} . \mathrm{CO}_{2} /\right.$ pass. $\left.\mathrm{km}\right)$ for currency value $(\mathrm{R} \$)$.

Therefore, a critical analysis of the results should be made, in which the green logistics cost scenarios meet the restrictions of the method (MPTS-URB) to meet demand, reducing the consumption of fossil fuels, reducing $\mathrm{CO} 2$ emissions and economic viability, the scenario may be accepted, otherwise, the back-analysis should be made, turning to Phase 2 (economic Survey) and Phase 3 (Sustainable Planning).

Next, Figure 2 schematically shows MPTS-URB. 

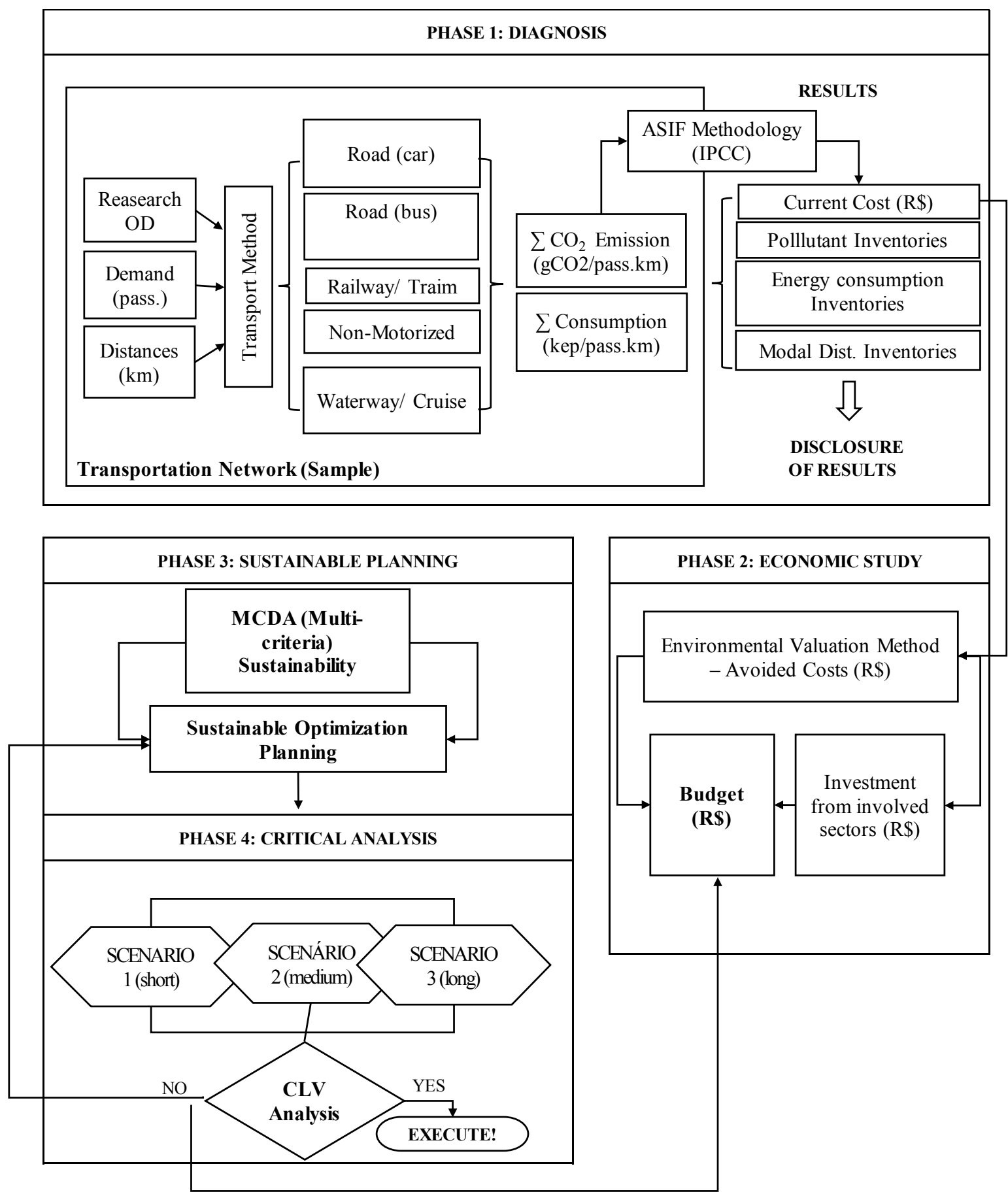

Figure 2. Sustainable Planning Method of Urban Passenger Transportation (MPTS-URB). Prepared by the author

\section{Final Considerations}

The systematic literature review made it possible to assume an understanding of the concepts of Green, Sustainable and Low Carbon Logistics. Among the authors surveyed, it was noted that such an understanding is not consensual, and can still generate divergent interpretations. Regarding the development of methods, measures and sustainable methods of transportation planning it was possible to identify greater activity in the field of green logistics for distribution of supplies through problems of green routing, and applied primarily motivated by business and industry.

Research seeking to study other sources of fuel (biomass) as an alternative to reduce emissions of pollutants is more present in Brazil, as well as methods of Environmental Valuation, which were heavily studied in the country. On the other hand, the transport logistics with natural resources sustainability criteria and reduction of anthropogenic gases was more identified between studies 
from Canada and the UK, especially in the logistics supply chain and freight transportation.

Finally, it can be concluded that methods to improve the performance of transport with a view to sustainability should consider, in addition to economic aspects and demand and capacity related to energy use, the conservation of natural resources, reduction of pollutant emissions and management of greenhouse gases, since they appraise the environmental efficiency with the same intensity as the economic and social, motivating transport optimization jointly between them.

As a future step and motivation to other works and authors, it is possible to see the application of the MPTS-URB method sample environment with the estimation of green logistics costs (CLV) for projection of more sustainable transport network scenarios.

\section{REFERENCES}

[1] ANDRADE, Daniel Caixeta et al. Degradação ambiental e teoria econômica: algumas reflexões sobre uma "economia dos ecossistemas”. Economia, v. 12, n. 1, 2011.

[2] BERETON, PEARL; KITCHENHAM, BARBARA A.; BUDGEN, DAVID; TURNER, MARK; KHALIL, MOHAMED (2007). Lessons from Applying the Sistematic Literature Review Process within the Software Engineering Domain. The Journal of System and Software, v. 80, p.571-583.

[3] BLOWERS, Andrew. Planning for a sustainable environment. Routledge, 2013.

[4] BORGES, Claudia. Ministério das Cidades debate projeto de lei em todo o país. In: JORNAL DO COMÉRCIO JC Logística. Edição de 20 de abr. de 2006. Porto Alegre. Disponível em> http://www.jc.plugin.com.br/ noticias.aspx?pCodigoArea $=47>$ Acesso em: 30 de novembro de 2015

[5] BRUNDTland, G. H. (Org.) Nosso Futuro Comum. Rio de Janeiro: FGV, 1987.

[6] CILIBERTI, F., Pontrandolfo, P., Scozzi, B. Logistics social responsibility: Standard adoption and practices in Italian companies. Int. J. Production Economics, V. 113, pp. 88106, 2008.

[7] COOK, D.J.; MULROW, C.D.; HAYNES, R.B. Systematic reviews: synthesis of best evidence for clinical decisions. Annals of Internal Medicine, v.126, n.5, pp.376-380, 1997.

[8] DA COSTA, Marcelo Ednan Lopes et al. Respostas de protesto na disposição a pagar espontânea e induzida nas técnicas de lances livres e referendo pelo método de valoração contingente. Biodiversidade, v. 14, n. 1, 2015.

[9] D`AGOSTO, M. A. Transporte, uso de energia e impactos ambientais: uma abordagem introdutória - 1.ed. - Rio de Janeiro. Elsevier, 2015.

[10] D’AGOSTO, Márcio; RIBEIRO, Suzana Kahn. Eco-efficiency management program (EEMP) - a model for road fleet operation. Transportation Research Part D: Transport and Environment, v. 9, n. 6, p. 497-511, 2004.

[11] DE QUEIROZ RIBEIRO, Luiz Cesar. O FUTURO DAS METRÓPOLES desigualdades e governabilidade. Letra Capital Editora LTDA, 2015.

[12] DEMIR, Emrah; BEKTAŞ, Tolga; LAPORTE, Gilbert. A comparative analysis of several vehicle emission models for road freight transportation. Transportation Research Part D: Transport and Environment, v. 16, n. 5, p. 347-357, 2011.

[13] DE OLIVEIRA, Gláucia Maia; DA SILVA, Antônio Nélson Rodrigues. Desafios e perspectivas para avaliação e melhoria da mobilidade urbana sustentável: um estudo comparativo de municípios brasileiros. TRANSPORTES, v. 23, n. 1, p. 59-68, 2015.

[14] DE OLIVEIRA, C. M. Aprimorando a Sustentabilidade da Logística por meio da Gestão Sustentável do Transporte de Carga. In: XXIII ANPET-Congresso Nacional de Pesquisa e Ensino em Transportes, 2014, Curitiba, 2014.

[15] DE PESQUISA ENERGÉTICA, EPE-Empresa. Balanço Energético Nacional 2013; 2014. Disponível em: $<$ http://www.mme. gov. br/ $>$ Acesso em: 04 de maio de 2016.

[16] ENSSLIN, L.; MONTIBELLER, G. N.; NORONHA, S. M. 2001. Apoio à decisão: metodologias para estruturação de problemas e avaliação multicritério de alternativas. Florianópolis: Insular.

[17] EMA (2016) - Economia do Meio Ambiente - Valoração dos Custos Ambientais. Rio de Janeiro, RJ. Disponível em: < http://www.economiadomeioambiente.com.br/>. Acesso em: 04 de maio de 2016.

[18] ERICSSON, Eva; LARSSON, Hanna; BRUNDELL-FREIJ, Karin. Optimizing route choice for lowest fuel consumption-potential effects of a new driver support tool. Transportation Research Part C: Emerging Technologies, v. 14, n. 6, p. 369-383, 2006.

[19] ERDOĞAN, Sevgi; MILLER-HOOKS, Elise. A green vehicle routing problem. Transportation Research Part E: Logistics and Transportation Review, v. 48, n. 1, p. 100-114, 2012.

[20] FERREIRA, Ronaldo da S. et al. Modelo DEA online para determinar a eficiência energética de embarcações. In: XXIX ANPET-Congresso Nacional de Pesquisa e Ensino em Transportes, 2015, Ouro Preto-MG. 2015.

[21] FORRESTER, J. (1975). The collected papers of Jay Forrester, Wright Allen Press, 1975. Determining The Future Quality Of A City.

[22] GUIMARAES, Vanessa de A. et al. Análise da evolução da eficiência energética no setor de transporte brasileiro. In: XXVII ANPET-Congresso Nacional de Pesquisa e Ensino em Transportes, 2013, Belém-PA. 2013.

[23] IAEA (2006) - Brazil: a country profile on sustainable energy development. International Atomic Energy Agency [et al.]. - Library Cataloguing in Publication Data. Vienna: The Agency, 2006. 266p.

[24] IPCC (1996) - Good Practice Guidance and Uncertainty Management in National Greenhouse Inventories - Revised 1996 IPCC Guidelines for National Greenhouse Gas - 
Intergovernmental Panel on Climate Change, United Nations Environment Program, the Organization for Economic Cooperation and Development and The International Energy Agency, London, United Kingdom.

[25] KAHN, Suzana. Reflexões sobre sustentabilidade urbana. Ciência e Cultura, v. 67, n. 1, p. 4-5, 2015.

[26] KOBAYASHI, Shigeki; PLOTKIN, Steven; RIBEIRO, Suzana Kahn. Energy efficiency technologies for road vehicles. Energy Efficiency, v. 2, n. 2, p. 125-137, 2009.

[27] LANDMANN, Marcelo Camilli; RIBEIRO, Helena; DEÁK, Csaba. Uma proposta metodológica para estimar o custo da poluição do ar nas análises de viabilidade de sistemas de transportes urbanos. TRANSPORTES, v. 15, n. 1, 2007.

[28] LAI, K. e Wong, C. Green logistics management and performance: Some empirical evidence from Chinese manufacturing exporters. Omega, v. 40, pp. 267-282, 2012. Doi:10.1016/j.omega.2011.07.002 95 .

[29] LAI, K., Wong, C. W. Y. e Cheng, T. C. E. Ecological modernisation of Chinese export manufacturing via green logistics management and its regional implications. Technological Forecasting \& Social Change. V. 79, pp. 766 770, 2012. Doi:10.1016/j.techfore.2011.10.004.

[30] LEAL, Ilton Curty; MÁRCIO DE ALMEIDA, D.'Agosto. Modal choice evaluation of transport alternatives for exporting bio-ethanol from Brazil. Transportation Research Part D: Transport and Environment, v. 16, n. 3, p. 201-207, 2011.

[31] LEAL JR, I. C.; D'AGOSTO, M. A. Melhoria da Ecoeficiência no Transporte Rodoviário de Produtos Perigosos. Transporte e Transformação XVI, Brasília: Positiva, 2012

[32] LIN, Canhong et al. Survey of green vehicle routing problem: past and future trends. Expert Systems with Applications, v. 41, n. 4, p. 1118-1138, 2014.

[33] LIIMATAINEN, Heikki; PÖLLÄNEN, Markus. Trends of energy efficiency in Finnish road freight transport 19952009 and forecast to 2016. Energy Policy, v. 38, n. 12, p. 7676-7686, 2010.

[34] MAIA, A. G.; ROMEIRO, A. R.; REYDON, B. P. Valoração dos recursos ambientais: metodologias e recomendações. (Texto para Discussão) Campinas: Unicamp. Instituto de Economia, mar. 2004. 39p, n. 116. Disponível em:

$<$ http://www.eco.unicamp.br/docprod/downarq.php?id=183 $3 \& \mathrm{tp}=\mathrm{a}>$. Acesso em 07 de abril de 2016.

[35] MCKINNON, A., Cullinane, S., Browne, M., Whiteing, A. Green logistics: improving the environmental sustainability of logistics. Londres, Philadelfia, Nova Delhi. Kogan Page, 2010. V. 1.

[36] MÁRCIO DE ALMEIDA, D.'Agosto; RIBEIRO, Suzana Kahn; DE SOUZA, Cristiane Duarte Ribeiro. Opportunity to reduce greenhouse gas by the use of alternative fuels and technologies in urban public transport in Brazil. Current Opinion in Environmental Sustainability, v. 5, n. 2, p. 177-183, 2013.

(http://www.sciencedirect.com/science/article/pii/S1877343 513000304)
[37] MARCIO DE ALMEIDA, D.'Agosto; OLIVEIRA, Cintia Machado; DO COUTO ASSUMPÇÃO, Fabiana. Alternativas energéticas para o transporte público urbano no Rio de Janeiro: uma análise utilizando Inventário de Ciclo de Vida (ICV). TRANSPORTES, v. 22, n. 1, p. 76-97, 2014.

[38] MARTINS, Karin Regina de Casas Castro. Proposta metodológica para planejamento energético no desenvolvimento de áreas urbanas. $\mathrm{O}$ potencial da integração de estratégias e soluções em morfologia e mobilidade urbanas, edifícios, energia e meio ambiente: o caso da operação urbana Água Branca, no município de São Paulo. 798p. Tese de Doutorado. FAUUSP, São Paulo, 2010.

[39] MENON, A.; Bharadw, A. J. S. G..; Adidam, P. T.; Edilson, S. W. (1999) Antecedents and consequences of marketing strategy making: a model and a test. Journal of Marketing, $63,2,18-40$

[40] NOVAES, A. G. Logística e gerenciamento da cadeia de distribuição: estratégia, operação e avaliação.Editora Campus, Rio de Janeiro, RJ, 2004.

[41] ORTIZ, R. A. Valoração econômica ambiental. In: MAY, P.; LUSTOSA, M. C.; VINHA, V. da (Orgs). Economia do meio ambiente: teoria e prática. Rio de Janeiro: Elsevier, 2003.

[42] ORTIZ, Ramon Arigoni; MARKANDYA, Anil; HUNT, Alistair. Willingness to pay for mortality risk reduction associated with air pollution in São Paulo. Revista Brasileira de Economia, v. 63, n. 1, p. 3-22, 2009.

[43] ORTIZ, Ramon Arigoni et al. Morbidity costs associated with ambient air pollution exposure in Sao Paulo, Brazil. Atmospheric Pollution Research, v.2, n.4, p. 520-529, 2011.

[44] PEARCE, D.W., 1993. Economic Values and the Natural World. London: Earthscan Publications: CSERGE, 1993. $129 \mathrm{p}$.

[45] Intergovernmental Panel on Climate Change (IPCC), 1997. Revised 1996 IPCC Guidelines for National Greenhouse Gas Inventories - The Reference Manual - Volume 3 Energy. Intergovernmental Panel on Climate Change, United Nations Environment Program, the Organization for Economic Cooperation and Development and the International Energy Agency, London, United Kingdom.

[46] QUIUMENTO, F. Logística Verde: Uma nova visão para a Logística com atividade humana integrada ao ambiente. 2011.

[47] ROMEIRO, A. R.; MAIA, A. G. Avaliação de custos e benefícios ambientais. Brasília: Escola Nacional de Administração Pública, 2011

[48] ROSA, Luiz Pinguelli; RIBEIRO, Suzana Kahn. The present, past, and future contributions to global warming of $\mathrm{CO} 2$ emissions from fuels. Climatic Change, v. 48, n. 2-3, p. 289-307, 2001.

[49] SANCHEZ-RODRIGUES, V., Potter, A. e Naim, M. M. The impact of logistics uncertainty on sustainable transport operations. International Journal of Physical Distribution \& Logistics Management Vol. 40 No. 1/2, pp. 61-83, 2010.

[50] SANTOS, ANDREA SOUZA; RIBEIRO, SUZANA 
KAHN. The role of transport indicators to the improvement of local governance in Rio de Janeiro City: A contribution for the debate on sustainable future. Case Studies on Transport Policy, v. 1, p. 01, 2015.

[51] SANTOS, ANDREA SOUZA; RIBEIRO, SUZANA KAHN. The use of sustainability indicators in urban passenger transport during the decision-making process: the case of Rio de Janeiro, Brazil. Current Opinion in Environmental Sustainability (Print), v. 5, p. 251-260, 2013.

[52] SARKIS, J., Meade, L. M. e Talluri, S. E-logistics and the natural environment. Supply Chain Management: An International Journal, Vol. 9 Iss: 4 pp. 303 - 312, 2004.

[53] SARKIS, J., Zhu, Q. e Lai, K., An organizational theoretic review of green supply chain management literature. Int. J. Production Economics, V. 130, pp.. 1-15, 2011.

[54] SEABRA, Luciany Oliveira; TACO, Pastor Willy Gonzales; DOMINGUEZ, Emílio Merino. Sustainability in transport: from concept to public policies of urban mobility. Public Transport Magazine: ANTP, 2013

[55] SCOTT, Cathy; URQUHART, Neil; HART, Emma. Influence of topology and payload on $\mathrm{CO}_{2}$ optimised vehicle routing. In: Applications of Evolutionary Computation. Springer Berlin Heidelberg, 2010. p. 141-150.

[56] SILVEIRA, V. C.; CIRINO, J. F.; PRADO FILHO, J. F. Valoração econômica da Área de Proteção Ambiental estadual da Cachoeira das Andorinhas - MG. Revista Árvore, v. 37, n. 2, p. 257-266, 2013.

[57] SONG, Mingzhu et al. A simulation-based approach for sustainable transportation systems evaluation and optimization: theory, systematic framework and applications. Procedia-Social and Behavioral Sciences, v. 96, p. 2274-2286, 2013.

[58] STANLEY, John K.; HENSHER, David A.; LOADER, Chris. Road transport and climate change: stepping off the greenhouse gas. Transportation Research Part A: Policy and Practice, v. 45, n. 10, p. 1020-1030, 2011.

[59] STEENHOF, Paul; WOUDSMA, Clarence; SPARLING, Erik. Greenhouse gas emissions and the surface transport of freight in Canada. Transportation Research Part D: Transport and Environment, v. 11, n. 5, p. 369-376, 2006.

[60] STEINEBACH, Gerhard; GUHATHAKURTA, Subhrajit; HAGEN, Hans (Ed.). Visualizing sustainable planning. Springer, 2009.

[61] TERM (2000). Transport and Environment Reporting Mechanism - Caminhamos na direção certa? Indicadores sobre a integração transportes-ambiente na União Europeia; Responsável pelo sumário: Agência Européia do Ambiente, impresso na Bélgica em janeiro de 2000. Disponível em: $<$ http://eea.eu.int>.

[62] TRANFIELD, David; DENYER, David; SMART, Palminder. Towards a methodology for developing evidence - informed management knowledge by means of systematic review. British journal of management, v. 14, n. 3, p. 207-222, 2003.

[63] TSENG, M., Lin, R., Lin, Y., Chen, R. e Tan, K. Close-loop or open hierarchical structures in green supply chain management under uncertainty. Expert Systems with Applications, V. 41, PP. 3250-3260, 2013.

[64] UHEREK, Elmar et al. Transport impacts on atmosphere and climate: Land transport. Atmospheric Environment, v. 44, n. 37, p. 4772-4816, 2010.

[65] VALENTE, A.M.: Passaglia, E.; Novaes, A.G. Gerenciamento de Transporte e Frotas. $2^{\mathrm{a}}$ ed. rev. São Paulo: Cengage Learning, 2012.

[66] VASCONCELLOS, Eduardo Alcântara. Transporte urbano, espaço e eqüidade: análise das políticas públicas. Annablume, 2001.

[67] VASCONCELLOS, Eduardo Alcântara. Transporte urbano nos países em desenvolvimento: reflexões e propostas. Annablume, 2000.

[68] VASCONCELLOS, Eduardo Alcântara de; CARVALHO, Carlos Henrique Ribeiro de; PEREIRA, Rafael Henrique Moraes. Transporte e mobilidade urbana. 2011.

[69] VIEIRA, F. R.; BARBOSA, C. de J. O método de valoração contingente (MAC): uma abordagem teórica. Revista Enciclopédia Biosfera, Centro Científico Conhecer, v. 8, n. 15, p. 2492-2510, 2012.

[70] VYAS, A. D.; PATEL, D. M.; BERTRAM, K. M. (February 2013). Potential for Energy Efficiency Improvement Beyond the Light-Duty-Vehicle Sector. Transportation Energy Futures Series. Prepared for the U.S. Department of Energy by Argonne National Laboratory, Argonne, IL. DOE/GO-102013-3706. 82 pp.

[71] WMO/UNEP (1990). Climate Change. The IPPC Response. World Meteorological Organization and United Nation Environmental Program. Luizane, Suiça.

[72] World Population Prospects: The 2015 Revision. United Nations, Department of Economic and Social Affairs, Population Division. New York, 2015. Population at mid-year. Disponível em: $<$ http://esa.un.org/unpd/wpp/Dow nload/Standard/Population/>. Acesso em: junho 2016.

[73] YANG, J., et al., Low-carbon city logistics distribution network design with resource deployment. Journal of Cleaner Production, pp.1-6 .2013.

[74] XUEZHONG, C., Linlin, J. e Chengbo, W. Business process analysis and implementation strategies of greening logistics in appliances retail industry. Energy Procedia 5, 332-336, 2011.

[75] ZAMCOPÉ, Fábio Cristiano et al. Modelo para avaliar o desempenho de operadores logísticos: um estudo de caso na indústria têxtil. Gestão \& Produção, v. 17, n. 4, p. 693-705, 2010.

[76] ZHANG, Zhong Xiang; BARANZINI, Andrea. What do we know about carbon taxes? An inquiry into their impacts on competitiveness and distribution of income. Energy policy, v. 32, n. 4, p. 507-518, 2004.

[77] ZHU, Q., Sarkis, J., Cordeiro, J.J., Lai, K. Firm-level correlates of emergent green supply chain management practices in the Chinese context. Omega, v. 36, pp. $577-591$, 2008. 